\title{
BAY LEAF (SYZYGIUM POLYANTHUM) EXTRACT GEL EFFECT ON TNF- A EXPRESSION IN TRAUMATIC ULCERS HEALING PROCESS
}

\author{
Annisha Savira*, Rochman Mujayanto**, Musri Amurwaningsih ${ }^{* \star *}$
}

* Program Pendidikan Sarjana Kedokteran Gigi, Fakultas Kedokteran Gigi, Universitas Islam Sultan Agung

** Departemen Ilmu Penyakit Mulut, Fakultas Kedokteran Gigi, Universitas Islam Sultan Agung

*** Departemen Ilmu Kesehatan Gigi Masyarakat, Fakultas Kedokteran Gigi, Universitas Islam Sultan Agung

Correspondence : Rohman Mujayanto, Departemen Ilmu Penyakit Mulut Fakultas Kedokteran Gigi, Universitas Islam Sultan

Agung, Jln. Raya Kaligawe KM. 4 Semarang 50012 ph. (024)6583584 fax. (024)6594366.

Email : rochman.mujayanto@unissula.ac.id

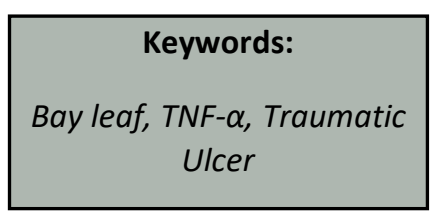

\begin{abstract}
Background: Traumatic ulcers were injuries that occur to the epithelium and basement membrane, due to physical, mechanical, or chemical trauma. The healing process of traumatic ulcers was divided into three main phases, namely inflammatory, proliferation, and maturation phase. TNF- $\alpha$ as a proinflammatory mediator worked 2-3 days which later would be replaced by an antiinflammatory mediator. This research aimed to determine the impact of bay leaf extract gel, which had a very high anti-inflammatory content, on TNF- $\alpha$ expression in accelerating the ulcers healing process.

Method: This research method was an in vivo experimental laboratory research using a post-test only control design. The sample consists of 20 rats divided into four groups, namely, the control group on day 1 , control groups on day 3 , treatment groups on 1st day, and treatment groups on 3rd day. Rats were made traumatic ulcers on the lower lip mucosa and were given bay leaf extract gel in the morning and evening. The tissue was then made into a histological preparation and given immunohistochemical staining to see TNF- $\alpha$.

Result: The results showed the mean of cells expressing TNF- $\alpha$ in the bay leaf gel extract group on the 1 st and 3 rd days has $P>0.05$. Independent T-test on 1 st day dan 3rd group showed a significant difference in TNF- $\alpha$ expression in the control and treatment groups.

Conclusion: The conclusion obtained in this study was bay leaf extract gel had a significant effect on the expression of TNF- $\alpha$ in the traumatic ulcers healing process.
\end{abstract}

\section{PENDAHULUAN}

Ulkus mukosa mulut merupakan luka yang terjadi lebih dari 3 hari akibat adanya kerusakan pada epitelium dan membran basalis. Ulkus yang paling sering ditemukan pada rongga mulut adalah ulkus traumatikus. Ulkus traumatikus disebabkan oleh adanya trauma fisik, mekanis dan kimia1. Ulkus traumatikus pada rongga mulut ditandai dengan adanya lesi berbentuk bulat dengan dasar putih dikelilingi warna kemerahan yang biasanya menyebabkan rasa nyeri².
Proses penyembuhan ulkus traumatikus terbagi 3 tahap utama diantaranya fase inflamasi, proliferasi dan remodelling. Fase inflamasi terjadi paling awal saat terjadinya luka. Fase ini menyebabkan terjadinya perubahan vaskular dan seluler pada tempat terjadinya luka ${ }^{3}$. Perubahan vaskuler menyebabkan adanya vasodilatasi pembuluh darah dan perubahan seluler menyebabkan terjadinya migrasi sel-sel leukosit. Salah satu sel yang berperan penting pada fase inflamasi adalah sel makrofag 4 . 
Sel makrofag pada fase inflamasi dibagi menjadi 2, diantaranya makrofag proinflamasi (M1) dan makrofag antiinflamasi (M2). Makrofag proinflamasi dihasilkan langsung saat awal terjadi luka sampai 36 jam kemudian untuk membantu neutrofil melakukan fagositosis, opsonisasi dan lisis bakteri4. Tugas makrofag proinflamasi digantikan oleh makrofag antiinflamasi untuk menyajikan antigen dan melepaskan platelet, thrombin, fibrinektin. Makrofag antiinflamasi memberikan sinyal untuk growth factor, kolagen dan sel lainnya untuk melanjutkan fase penyembuhan selanjutnya, diantaranya proliferasi dan remodeling 5 .

Sitokin yang berperan penting yang dihasilkan oleh makrofag proinflamasi adalah TNFa. TNF-a dihasilkan sangat banyak saat awal terjadinya luka untuk melakukan apoptosis dan meningkatkan permeabilitas pembuluh darah ${ }^{3}$. TNF- $\alpha$ digunakan sebagai perantara sel T serta sel B untuk membentuk aktifitas neutrofil serta makrofag untuk membangun sistem imun. Kerja TNF- $\alpha$ yang berlebihan akan menyebabkan terhambatnya proses angiogenesis, migrasi sel fibroblast yang menyebabkan penyembuhan luka menjadi lambat ${ }^{6}$.

Pemberian peran antagonis untuk sitokin proinflamasi adalah cara yang tepat untuk mempercepat proses penyembuhan luka ${ }^{6}$. Penelitian ini menggunakan daun salam yang memiliki kandungan antiinflamasi yang sangat tinggi untuk menekan kerja TNF- $\alpha$, sehingga proses penyembuhan berlansung lebih cepat ${ }^{7}$. Daun salam dengan kandungan tanin sebagai antibakteri, essential oil sebagai antiseptic dan flavonoid sebagai antiinflamasi mampu mempercepat kerja TNF- $\alpha$ sehingga proses penyembuhan ulkus traumatikus berlangsung dengan cepat ${ }^{8}$.

Tujuan penelitian ini adalah untuk mengetahui dan menganalisi pengaruh ekstrak daun salam (Syzygium Polyanthum) dalam mengurangi jumlah TNF- $\alpha$ sebagai sitokin pro-inflamasi dalam mempercepat proses penyembuhan ulkus traumatikus.

\section{METODE PENELITIAN}

Penelitian ini telah mendapat ijin dari Komite Tim Etik Penelitian Fakultas Kedokteran Gigi Universitas Islam Sultan Agung dengan nomor 102/B.1 KEPK/SA-FKG/VII/2019. Jenis penelitian ada penelitian laboratoris dengan desain eksperimental post test only control grup.

Sampel berjumlah 20 ekor tikus wistar jantan yang terbagi 4 kelompok. Kelompok pertama ialah kelompok kontrol di hari ke 1, kelompok kedua ialah kelompok kontrol di hari ke 3 , kelompol ketiga ialah kelompok perlakuan di hari ke 1, dan kelompok keempat adalah kelompok perlakuan di hari ke 3 . Kelompok kontrol diberi gel ekstrak carbomer dan kelompok perlakuan diberikan gel ekstrak daun salam.

Gel ekstrak daun salam dibuat dengan memilih daun salam yang masih segar. Daun salam yang sudah dipilih kemudian dikeringkan menggunakan oven dalam waktu 2-3 hari. Daun salam kering lalu dihaluskan dengan menggunakan blender dan ditimbang sebanyak 250 gram. Daun salam yang sudah menjadi bubuk kemudian dicampur dengan menggunakan etanol 96\% dengan perbandingan 1:9, kemudian dimaserasi selama 3 hari dengan cara diaduk sehari $2 x$ selama 15 menit agar tercampur merata ${ }^{9}$. Tiga hari setelah proses maserasi, ampas daun salam yang mengendap disaring dengan menggunakan kain flanel dan vacuum filter. Filtrat daun salam kemudian diuapkan dengan menggunakan rotary evaporator sampai menjadi ektrak kental daun salam. Ekstrak yang telah didapat kemudian dicampur dengan larutan carbomer 1,5\%, TEA 1 gram, metal paraben, dan gliserin. Semua bahan diaduk sampai homogen dan tidak ada partikel yang berbeda ${ }^{10}$. 
Tikus wistar jantan yang sudah dipilih secara acak kemudian dibagi rata menjadi 5 ekor tikus pada tiap kelompok. Tikus kemudian diadaptasi selama 5 hari, setelah itu dibuat ulkus pada mukosa labial ${ }^{11}$. Tikus diberikan anastesi topikal berupa benzocaine $10 \%$ selama 5 menit, setelah tikus tenang burnisher panas dengan diameter $2 \mathrm{~mm}$ diletakan pada mukosa labial tikus selama 1 detik. Proses pembuatan ulkus dilakukan pada 20 sampel ekor tikus kemudian ditunggu 2-3 hari sampai muncul ulkus traumatikus ${ }^{12}$.

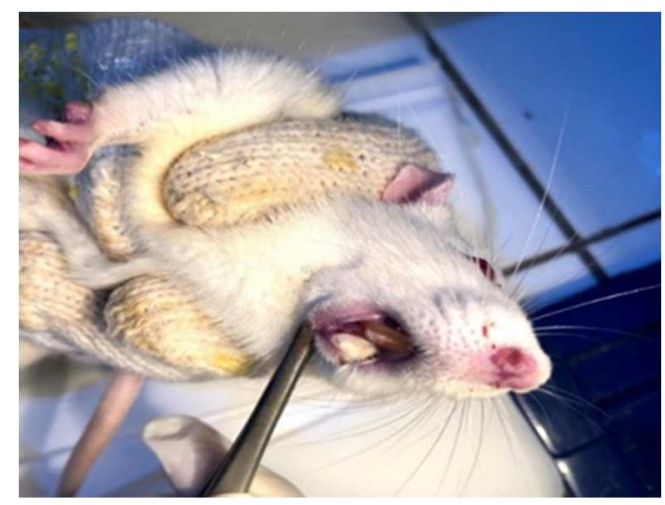

Gambar 1. Ulkus Traumatikus pada mukosa labial tikus.

Ulkus terbentuk 3 hari setelah pemberian luka, kemudian diaplikasikan gel carbomer sebagai kontrol dan gel ekstrak daun salam. Pemberian gel pada ulkus dilakukan setiap hari pada pagi dan sore. Hari pertama dan ke 3 setelah perlakuan, tikus kemudian didekapitasi dan dianastesi dengan menggunakan kloroform peri inhalasi ${ }^{12}$. Kelompok tikus kontrol dan perlakuan kemudian dilakukan pengambilan jaringan ulkus sesuai dengan bentuknya dengan menggunakan gunting. Jaringan dengan ulkus kemudian dimasukan kedalam container berisi larutan formalin, kemudian dibuat preparat histopatologi dan dilakukan pembacaan ekspresi TNF- ${ }^{11}$.

Ekspresi TNF- $\alpha$ didapatkan dari hasil perhitungan rata-rata sel makrofag yang mengekspresikan TNF- $\alpha$ dengan mikroskop perbesaran 400 kali. Hasil positif jika ditemukan inti sel yang besar dengan sitoplasma berwarna kecoklatan atau hitam keunguan ${ }^{13}$. Hasil negatif jika ditemukan inti sel yang kecil atau besar dengan sitoplasma berwarna kebiruan atau jernih. Penghitungan dengan merata-rata jumlah sel leukosit yang mengekspresikan TNF- $\alpha$ dalam 5 lapang pandang ${ }^{14}$.

Data yang diambil dari pewarnaan imunohistokimia adalah data semi kuantitatif dengan allred score dengan ketentuan sebagai berikut : $0-1=$ negatif, $2-3=$ positif ringan , $4-6=$ positif sedang, $7-8=$ positif tinggi dan data kuantitatif yang dinilai menggunakan skor Hotspot, didasarkan pada banyaknya warna coklat yang dihasilkan dari pewarnaan TNF-a. Data yang telah terkumpul dilakukan analisa data menggunakan SPSS. Digunakan uji normalitas Shapiro Wilk (jumlah sampel $<50$ per kelompok) dan uji homogenitas Levene Statistic. Apabila data normal dan homogen (asymp sig $>0.05$ ), data dianalisis menggunakan uji independent $T$ - test. Bila data tidak normal dan tidak homogen (asymp sig<0.05) maka dianalisis dengan uji Mann-Whitney.

\section{HASIL PENELITIAN}

Tabel 1, menunjukan intesitas allred score paling rendah berada pada kelompok daun salam hari ke 3 yang berarti pada kelompok tersebut ekspresi TNF- $\alpha$ paling rendah.

Tabel 1. Intensity Allred Score

\begin{tabular}{cc}
\hline Kelompok & $\begin{array}{c}\text { Intensity Allred } \\
\text { score }\end{array}$ \\
\hline Kontrol hari ke 1 & 3,2 \\
\hline Kontrol hari ke 3 & 2,4 \\
\hline Daun salam hari ke1 & 2,2 \\
\hline Daun salam hari ke 3 & 2 \\
\hline
\end{tabular}

Tabel 2, menunjukkan jumlah rerata ekspresi TNF- $\alpha$ kelompok ekstrak daun salam lebih rendah dibanding dengan kelompok kontrol, diketahui kelompok daun salam hari ke 3 memiliki rerata ekspresi TNF- $\alpha$ terendah dan kontrol hari ke 3 dengan rerata ekspresi TNF- $\alpha$ tertinggi. 
Tabel 2. Jumlah rerata ekspresi TNF- $\alpha$

\begin{tabular}{ccccc}
\hline Kelompok & $\begin{array}{c}\text { Kontrol } \\
\text { hari ke } \\
\mathbf{1}\end{array}$ & $\begin{array}{c}\text { Kontrol } \\
\text { hari ke } \\
\mathbf{3}\end{array}$ & $\begin{array}{c}\text { Daun } \\
\text { salam } \\
\text { hari } \\
\text { ke 1 }\end{array}$ & $\begin{array}{c}\text { Daun } \\
\text { Salam } \\
\text { hari } \\
\text { ke 3 }\end{array}$ \\
\hline $\begin{array}{c}\text { Jumlah } \\
\text { sampel }\end{array}$ & 5 & 5 & 5 & 5 \\
\hline Rata-rata & 25,7 & 26,3 & 16,1 & 14,4 \\
\hline $\begin{array}{c}\text { Standar } \\
\text { deviasi }\end{array}$ & 1,41 & 0,98 & 2,29 & 1,44 \\
\hline
\end{tabular}

Analisis data dilanjutkan dengan uji normalitas yang didapatkan semua data terdistribusi normal dengan nilai $p<0.05$ dan uji homogenitas levene test didapatkan data homogen bernilai $p>0.05$ maka analisis digunakan uji Independent T-test.

Tabel 3 Hasil uji normalitas Shapiro-Wilk

\begin{tabular}{ccc}
\hline Kelompok & Sig $(\mathbf{P})$ & Keterangan \\
\hline $\begin{array}{c}\text { Kontrol hari ke } \\
1\end{array}$ & 0,14 & $\begin{array}{c}\text { Data } \\
\text { terdistribusi } \\
\text { normal }\end{array}$ \\
\hline $\begin{array}{c}\text { Kontrol hari ke } \\
3\end{array}$ & 0,99 & $\begin{array}{c}\text { Data } \\
\text { terdistribusi } \\
\text { normal }\end{array}$ \\
\hline $\begin{array}{c}\text { Daun salam } \\
\text { hari ke 1 }\end{array}$ & 0,35 & $\begin{array}{c}\text { Data } \\
\text { terdistribusi } \\
\text { normal }\end{array}$ \\
\hline $\begin{array}{c}\text { Daun salam } \\
\text { hari ke 3 }\end{array}$ & 0,93 & $\begin{array}{c}\text { Data } \\
\text { terdistribusi } \\
\text { normal }\end{array}$ \\
\hline
\end{tabular}

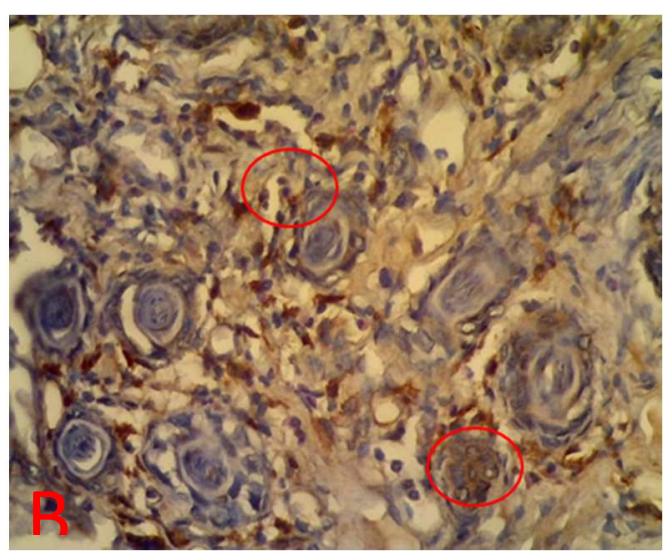

Tabel 4 Hasil uji homogenitas

\begin{tabular}{ccc}
\hline $\begin{array}{c}\text { Kenaikan } \\
\text { skor }\end{array}$ & Sig $(\mathbf{P})$ & Keterangan \\
\hline $\begin{array}{c}\text { Based on } \\
\text { mean }\end{array}$ & 0,07 & Data homogen \\
\hline
\end{tabular}

Hasil uji Independent $T$ test menunjukkan nilai 0.000 di hari ke 1 dan 0.000 di hari ke 3 $(P<0.05)$, berarti terdapat perbedaan pemberian gel ekstrak daun salam terhadap ekspresi TNF- $\alpha$ pada ulkus traumatikus pada hewan coba.

Tabel 5 Hasil uji Independent T-Test perkelompok hari

\begin{tabular}{ccccc}
\hline $\begin{array}{c}\text { Hari } \\
\text { ke }\end{array}$ & Kelompok & $\mathbf{P}$ & $\begin{array}{c}\text { Sig } \\
<\mathbf{0 , 0 5}\end{array}$ & Keterangan \\
\hline 1 & Daun & 0,00 & $\mathrm{P}<$ & Signifikan \\
& $\begin{array}{c}\text { Salam } \\
\end{array}$ & & 0,05 & \\
\cline { 2 - 4 } 3 & Kontrol & & & \\
\hline & $\begin{array}{c}\text { Daun } \\
\text { salam }\end{array}$ & 0,00 & $\begin{array}{c}\mathrm{P}< \\
0,05\end{array}$ & Signifikan \\
\hline
\end{tabular}

Pada pembacaan preparat hasil penelitian ditemukan inti sel dengan sitoplasma berwarna kecoklatan pada preparat histologi yang menunjukkan sel tersebut terdapat ekspresi TNF- $\alpha$.

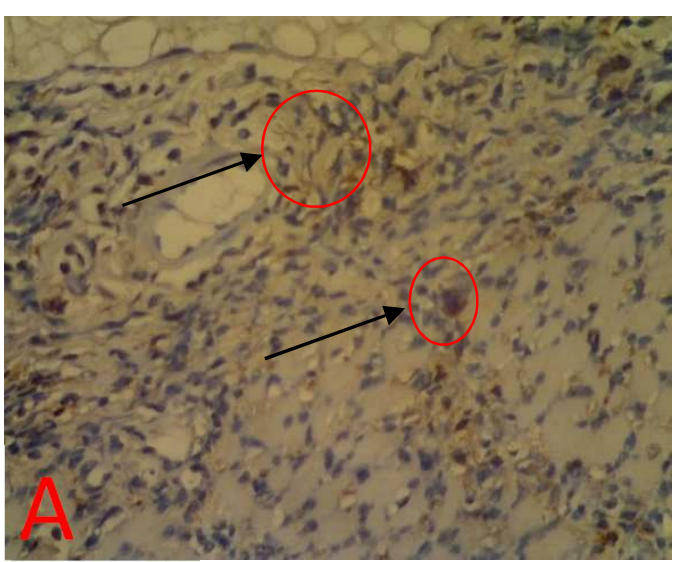

Gambar 2. Gambaran sel yang mengekspresikan TNF- $\alpha$ pada hari ke-1 berwarna kecoklatan pada kelompok kontrol (a) dan kelompok perlakuan (b) dan diamati dengan mikroskop perbesaran 400x 

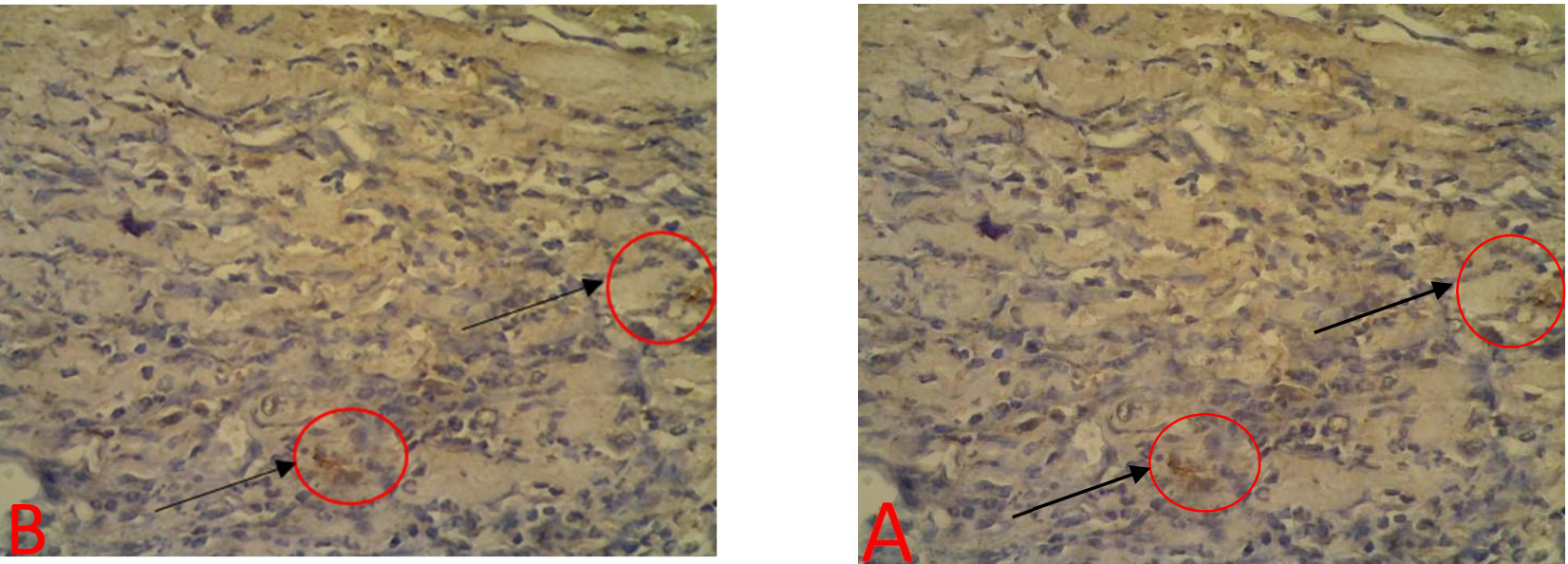

Gambar 3. Gambaran sel yang mengekspresikan TNF-a berwarna kecoklatan pada hari ke-3 pada kelompok kontrol (a) dan kelompok perlakuan (b) dan diamati dengan mikroskop perbesaran 400x

\section{DISKUSI}

Hasil dari penelitian ini adalah gel ekstrak daun salam pada kelompok perlakuan secara signifikan mampu mengurangi ekspresi TNF- $\alpha$ sehingga mampu mempercepat proses penyembuhan ulkus traumatikus.

Ekspresi TNF- $\alpha$ paling rendah ditemukan pada kelompok perlakuan hari ke 3 dan ekspresi terkuat ditemukan pada kelompok kontrol hari ke 3 . Data tersebut menunjukan bahwa pada kelompok perlakuan TNF- $\alpha$ memiliki perseberan paling sedikit, sehingga dapat diketahui bahwa gel ekstrak daun salam mempengaruhi ekspresi TNF- $\alpha$.

Proses penyembuhan ulkus traumatikus terbagi 3 tahap utama diantaranya fase inflamasi, proliferasi dan remodelling. Inflamasi merupakan suatu aktivitas yang berfungsi melindungi jaringan saat terjadi luka karena trauma fisik, trauma kimia dan trauma akibat adanya respon patologis dari jaringan tubuh². Inflamasi dalam upaya melindungi jaringan tersebut akan menginaktivasi atau membunuh organisme yang menyebabkan iritan dan mengatur proses penyembuhan ${ }^{4}$.

Makrofag yang dihasilkan saat fase inflamasi kemudian dibagi menjadi 2 diantaranya makrofag proinflamasi (M1) dan makrofag antiinflamasi (M2) ${ }^{4}$. Makrofag proinflamasi kemudian menghasilkan sitokin proinflamasi berupa TNF- $\alpha$ pada saat awal terjadinya luka. TNF- $\alpha$ berfungsi untuk melakukan apoptosis dan lisis pada tempat luka ${ }^{6}$.

TNF- $\alpha$ memiliki fungsi sebagai perantara untuk sel $\mathrm{T}$ dan sel $\mathrm{B}$ dalam membantuk aktivitas neutrofil dan makrofag untuk memberikan respon imun terhadap bakteri, virus dan jaringan yang terinfeksi ${ }^{5}$. Pemberian perlakuan untuk mempercepat kerja TNF- $\alpha$ sebagai sitokin proinflamasi adalah memberikan peran antagonisnya diantaranya dengan agen antiinflamasi. Daun salam sebagai obat herbal alami dengan kandungan flavonoid yang tinggi dapat digunakan untuk mengurangi TNF- $\alpha$ sebagai sitokin proinflamasi ${ }^{9}$.

Tiga kandungan gel ekstrak daun salam yang sangat berperan penting dalam proses penyembuhan ulkus adalah tanin, essential oil, dan flavonoid ${ }^{7}$. Tanin sebagai antibakteri mampu mengurangi produksi bakteri yang ada pada tempat terjadinya luka, essential oil sebagai antiseptik mampu mengurangi persebaran bakteri pada tempat terjadinya luka dan flavonoid sebagai antiinflamasi sebagai kandung yang tepat untuk mengurangi TNF- $\alpha$ sebagai agen proinflamasi ${ }^{8}$. 
Flavonoid sebagai antinflamasi bekerja dengan cara menghambat siklooksigenase sehingga sintetis prostaglandin dan stimuli hidroksilasi prolin terhambat, hal tersebut menyebabkan sel peradangan pada jaringan berkurang ${ }^{13}$. Peran flavaonoid pada proses penyembuhan ulkus traumatikus mampu meregulasi kerja TNF- $\alpha$. Molekul flavonoid seperti apigenin dan luetolitin mampu menjadi kontrol dari terbentuknya sitokin proinflamasi ${ }^{15}$. Molekul flavonoid tersebut mampu menghambat aktivasi jalur signaling intraseluler yang kemudian akan mempercepat proses kerja dari makrofag proinflamasi sehingga perannya digantikan oleh makrofag antiinflamasi ${ }^{16}$.

\section{KESIMPULAN}

Dapat ditarik kesimpulan bahwa gel ekstrak daun salam (Syzygium polyanthum) memiliki efek yang signifikan dalam menurunkan ekspresi TNF- $\alpha$ pada proses penyembuhan ulkus traumatikus mukosa mulut.

\section{DAFTAR PUSTAKA}

1. Bombeccari GP, Guzzi G, Pallotti F, Porrini M, Giannì $A B$, Spadari F. Large oral ulcer of tongue related to dental trauma. Stomatol Balt Dent Maxillofac J. 2017;19(19):51-4.

2. Mortazavi H, Safi Y. Diagnostic Features of Common Oral Ulcerative Lesions: An Updated Decision Tree. Int J Dent. 2016;20:14.

3. Angel PG, Kalangi S, Wangko S, Kedokteran AF, Sam U, Manado R. Gambaran Proses Radang Luka Postmortem Pada Hewan Coba. e-Biomedik. 2014;2(November).

4. Hermans MH. Wounds and Ulcers: Back to the Old Nomenclature. Hermans, Consult Inc. 2010;22(11):289-93.
5. Sinno H, Prakash S. Complements and the Wound Healing Cascade : An Updated Review. Hindawi, Pubishing Corp. 2013;2013:7.

6. Olmos G, Lladó J. Tumor Necrosis Factor Alpha: A Link between Neuroinflammation and Excitotoxicity. Hindawai, Pubishing Corp. 2014;2014:12.

7. Sumono A, Dharmayanti AWS. The use of bay leaf (Eugenia polyantha Wight) in dentistry. Dent J (Majalah Kedokt Gigi). 2016;41(3):147.

8. Silalahi M. Syzygium polyanthum (Wight) Walp. (Botani, Metabolit Sekunder dan Pemanfaatan). J Univ kristen Indones. 2017;10(1):1-16.

9. Uchti AF, Wahyuningsih SS. Variasi Konsentrasi HPMC Terhadap Stabilitas Fisik Gel Ektrak Etanol Daun Salam (Syzygium pholyanthum W). IJMS - Indones J Med Sci. 2015;2(2).

10. Roosevelt A, Akhir LO, Farmasi A, Karsa S, Studi P, Sandi DF, et al. Formulasi dan Uji Stabilitas Fisik Sediaan Gel Ekstrak Kulit Buah Rambutan (Nephelium lappaceum L.) Sebagai Obat Sariawan Menggunakan Variasi Konsentraso Carbopol. 2015;5:5-10.

11. Destri WC, Sudiana IK, Nugraha J. Potensi Ekstrak Jatropha Multifida Terhadap Ekspresi VEGF A[htous Ulcer Rat norvegicus. SainHealth. 2017;1(2):5-12.

12. Mujayanto R, Harijanti K, Hernawan I. Topical application of $1 \%$ ZnSO4 on oral ulcers increases the number of macrophages in normal or diabetic conditions of wistar rats. Dent J (Majalah Kedokt Gigi). 2016;49(3):133.

13. Mendrofa AN, Karsini I, Mulawarmanti D. Extract of mangrove leaf ( $A$. marina) accelerates the healing of traumatic ulcer. dentofasial. 2015;14(1):11-4.

14. Mohamad SH. Tumor Necrosis Factor-Alpha (TNF-a) Expression in Mice Infected with Aspergillus $\quad$ Fumigatus Using Immunohistochemichal Technique. Int J Sci. 2016;25(1):183-9.

15. Shahbaz M, Zaheer N. Modulation of Tnf- $A$ Level on Buccal Wound Healing. 2018;38(2):182-6.

16. Leyva-lópez N, Gutierrez-grijalva EP, Ambizperez DL, Heredia JB. Flavonoids as Cytokine Modulators: A Possible Therapy for Inflammation-Related Diseases. Int J Mol Sci. 2016;17(921):1-15. 